\title{
Laterális nyomásprofil számításával összefüggő problémák vizsgálata számítógépes szimulációval
}

\author{
FÁBIÁN Balázs, ${ }^{\mathrm{a}, \mathrm{b}}$ IMRE Attila, ${ }^{\mathrm{c}, \mathrm{d}}$ HORVAI György, ${ }^{\mathrm{a}, \mathrm{e}}$ és JEDLOVSZKY Pále, ${ }^{\mathrm{ef}, *}$ \\ ${ }^{a}$ BME Szervetlen és Analitikai Kémia Tanszék., 1111 Budapest, Szent Gellért tér 4 \\ ${ }^{b}$ Institut UTINAM, Université Bourgogne Franche-Comté, 16 route de Gray, F-25030 Besançon, Franciaország \\ ${ }^{c}$ MTA Energiatudományi Kutatóközpont, 1112 Budapest, Konkoly Thege Miklós út 29-33 \\ ${ }^{d}$ BME Energetikai Gépek és Rendszerek Tanszék, 1111 Budapest, Bertalan Lajos utca 4-6 \\ ${ }^{e}$ MTA-BME Müszaki Analitikai Kémiai Kutatócsoport, 1111 Budapest, Szt. Gellért tér 4. \\ ${ }^{f}$ Eszterházy Károly Egyetem, Kémiai és Élelmiszerkémiai Tanszék, 3300 Eger, Leányka utca 6.
}

\section{Bevezetés}

A tudomány évezredeken keresztül alapvetően kétféle módon közelítette meg a vizsgálni kívánt problémákat. A kísérleti tudományok a természetben megfigyelt jelenségeket rögzítették, lehetőleg kvalitatív módon, míg az elméleti tudományok értelmezési keretet próbáltak adni az ily módon rögzített adathalmazoknak. Az elmúlt háromnegyed évszázadban a számítógépek megjelenésével, elterjedésével, és a könnyen elérhető számítási kapacitás rohamos fejlődésével párhuzamosan azonban a fenti két klasszikus tudományos megközelítési mód mellé egy harmadik is felzárkózott: a számítógépes szimulációk módszere. Számítógépes szimuláció során a valódi vizsgálandó rendszert annak egy alkalmasan választott modelljével helyettesítjük - ennyiben a szimuláció az elméleti megközelítéssel rokon -, majd a modellrendszeren numerikus kísérleteket végzünk. A szimuláció tehát az elméletekkel szemben a kísérlet, a kísérletekkel szemben pedig az elmélet szerepét játssza.

A számítógépes szimulációs vizsgárlatok igen elterjedtekké váltak, hiszen a valódi kísérletekhez viszonyítva költségük elenyésző, valamint a kísérletileg csak nagy nehézségek árán vizsgálható rendszerek (pl. extrém körülmények, túlságosan korrozív anyagok) esetében is probléma nélkül végezhetőek. Természetesen sosem téveszthetjük szem elől, hogy a szimulációk a valódi rendszerek helyett csak azok modelljeit vizsgálják, így egyrészt a használt modell jóságát valódi kísérleti adatokkal való összevetésekkel mindig igazolni kell, másrészt a szimulációs vizsgálatokkal elért fontosabb megállapításokat lehetőség szerint szintén ellenőrizni kell kísérletes úton is.

Az elmúlt húsz évben kolloid- és felületkémiai jellegü problémák vizsgálatában is egyre nagyobb szerepet kaptak a számítógépes szimulációs módszerek. Kutatócsoportunkban ezek közül elsősorban fluid illetve szilárd-gáz határfelületek molekuláris szerkezetének, illetve ilyen felületeken végbemenő folyamatoknak a vizsgálatával foglalkoztunk. Fluid határfelületek számítógépes szimulációs vizsgálata során azonban nem várt nehézségekbe ütközhet a kutató.
Noha az ilyen felületek általában makroszkóposan síknak tekinthetők, molekuláris felbontásban e felületek érdesek, úgynevezett kapilláris hullámok tagolják őket. ${ }^{2}$ E molekulárisan érdes felület ráadásul időben is folyamatosan változik, így a felületi tulajdonságok érdemi, rendszeres hibától mentes vizsgálatához pillanatról pillanatra újra meg kell határozni az egyes fázisok valódi, kapilláris hullámok által érdesített határfelületét, vagy - ezzel egyenértékűen - a határfelületi molekulák teljes listáját. A határfelület tulajdonságait érintő érdemi vizsgálatokat csak akkor végezhetünk, ha elöször világosan elkülönítjük rendszerünkben a határfelületet a nem határfelületi részektől. Erre a célra fejlesztette ki csoportunk az ITIM (Identification of the Truly Interfacial Molecules) módszert, ${ }^{3,4}$ mely kitünő kompromisszumnak bizonyult a pontosság és számításigény tekintetében. ${ }^{5}$

Fluid határfelületek számítógépes szimulációs vizsgálatai során a megérdemeltnél lényegesen kevesebb figyelmet kaptak a nyomás oldalirányú komponensének felületre merőleges irányú profiljával kapcsolatos problémák. Ennek oka a nyomásprofil számításával kapcsolatos elvi és technikai nehézségekben rejlik. A nyomás ugyanis egy globális, egyebek között a részecskék közötti kölcsönhatásokkal kapcsolatban álló termodinamikai mennyiség, a profil számítása ugyanakkor óhatatlanul megköveteli e globális mennyiség felbontását, legalább közelítőleg, lokális járulékok összegére.

A cikk további részében csoportunknak a laterális nyomásprofil fluid határfelületeken való számításával kapcsolatos legújabb eredményeit foglaljuk össze. A 2. fejezetben e profilok számításával kapcsolatos technikai kérdéseket vesszük sorra. A 3-5. fejezetben három konkrét, laterális nyomásprofillal összefüggő kérdéssel, nevezetesen a felületi feszültség felületre merőleges irányú eloszlásával, a folyadékok túlhevítési határának becslésével, illetve az altató hatású molekulák hatásmechanizmusának értelmezésével kapcsolatos vizsgálatainkat ismertetjük. Míg az első kérdés egyértelműen a kolloidika tárgykörébe sorolható, a második inkább ipari-alkalmazott, míg a harmadik orvosbiológiai jellegü probléma.

\footnotetext{
*E-mail: jedlovszky.pal@uni-eszterhazy.hu
} 


\section{A laterális nyomásprofil számítása}

A nyomás molekuláris értelmezését legtöbbször a kinetikus gázelmélethez szokás kötni. ${ }^{6}$ Ezen értelmezés szerint a nyomás az edény falának egységnyi felületére a falnak ütődő részecskék által kifejtett erôtől származik, és ilyen módon a részecskék sebességével van kapcsolatban. Ez a megközelítés azonban rendszerünket ideális gáznak tekinti, azaz nem veszi figyelembe a részecskék között ható kölcsönhatásokat, melyek a fenti erőt, és így a nyomást is képesek megváltoztatni. (A részecskék közötti erős vonzás teszi lehetővé negatív nyomású állapotok létét is. ${ }^{7}$ ) A nyomástenzor $a b$ komponense tehát a következő alakban írható fel:

$$
p_{a b}=\frac{2}{V}\left(\frac{1}{2} \sum_{i} m_{i} v_{i}^{a} v_{i}^{b}-\Xi_{a b}\right)
$$

ahol $m_{i}$ az $i$-dik részecske tömege, $v_{i}^{a}$ és $v_{i}^{b}$ a sebességének $a$ illetve $b$ irányú komponense, $V$ a rendszer térfogata, $\Xi_{a b}$ pedig a viráltenzor megfelelő eleme. A kifejezés első tagja írja le a nyomás kinetikus gázelméletnek megfelelő, ideális járulékát, a viriál pedig a részecskék közötti kölcsönhatásból származó tagot. Egy adott részecskepár kölcsönhatásának a viriálhoz adott járuléka a két részecskét összekötő út mentén számított vonalmenti integrálként írható fel, az integrál értéke, valamint az innen származó nyomásjárulék helye azonban függ az integrálási út megválasztásától. Itt érhető tetten az a korábban már említett probléma, hogy a nyomás, és így a viriál egyes járulékait lokalizálni szeretnénk a profil számításához, azonban ezek a mennyiségek természetüknél fogva nem lokálisak.

A gyakorlatban a vonalmenti integrál számításához az integrálási út két speciális választása terjedt el: az Irving-Kirkwood kontúr egyszerűen a két részecskét összekötő egyenes szakasz, ${ }^{8}$ míg a Harasima kontúr az utat felbontja a felületre meröleges, illetve azzal párhuzamos járulékok összegére ${ }^{9}$ (1. ábra). Noha e két integrálási út használata elvileg különböző nyomásprofilokat eredményez, a laterális nyomásprofilok egymástól csak nagyon kis mértékben térnek el, ${ }^{10}$ köszönhetően a részecskék közötti kis távolságoknak. Laterális nyomásprofil számításánál a Harasima kontúr használatának több előnye is van. Az egyik ilyen előny, hogy - szemben az Irving-Kirkwood profillal ez az út akkor is használható, ha a részecskék közötti kölcsönhatás nem páronként additív. ${ }^{10} \mathrm{E}$ tény jelentősége igen nagy, hiszen még ha a szimuláció során alkalmazott potenciál páronként additív is, az elektrosztatikus kölcsönhatás hosszútávú járulékának kiszámítására alkalmazott Ewald összegzés ${ }^{11,12}$ vagy annak háló mentén alkalmazott variánsai (Particle Mesh Ewald, PME) $)^{13,14}$ reciprok térbeli tagja biztosan nem az. Az Ewald összegzésből származó laterális nyomásjárulék számítása így sem egyszerü feladat. Sonne és munkatársai ugyan megmutatták, hogyan lehet az Ewald összegzésből származó nyomásjárulékot kiszámítani, ${ }^{10}$ a teljes Ewald összegzés használata nagyobb rendszerek szimulációját kezelhetetlenül lassúvá teszi. A gyakorlatban ezért az a módszer terjedt el, hogy a szimulációt a teljes Ewald összegzésnél lényegesen gyorsabb PME módszer használatával végzik el, majd a nyomásprofilt a szimuláció során elmentett trajektórián hosszútávú korrekció nélkül, minél nagyobb levágási sugár alkalmazásával számolják. ${ }^{15-20}$ Megmutattuk azonban, hogy az alkalmazott potenciál ilyetén megváltoztatása a szimuláció és az analízis között akár több száz bar rendszeres hibát is okozhat a számított nyomásprofilban. ${ }^{21} \mathrm{E}$ probléma elkerülésének érdekében megmutattuk, hogyan számítható ki és lokalizálható az elektrosztatikus kölcsönhatás hosszútávú korrekciójának laterális nyomáshoz adott járuléka az sPME módszer ${ }^{14}$ alkalmazása mellett. ${ }^{21}$

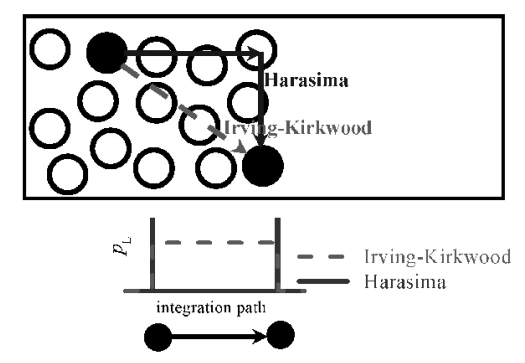

1. Ábra. Irving-Kirkwood (piros) és Harasima integrálási profil két részecske kölcsönhatása nyomásjárulékának számításakor (felül), illetve a laterális nyomásjárulék eloszlása az integrálási út mentén (alul).

A Harasima kontúr használatának másik komoly előnye abban áll, hogy míg az Irving-Kirkwood kontúr használata a két részecskét összekötő szakasz mentén egyenletesen oszlatja el a kölcsönhatásból származó nyomásjárulékot, a Harasima kontúr esetén ez a járulék fele-fele arányban a két részecskén lokalizálódik. Ilyen módon a teljes nyomás felbontható részecskékhez kötött járulékok összegére, a számítás során e járulékok a részecskékhez kötötten, azok tulajdonságaként tarthatók nyilván, ami nagymértékben megkönnyíti a nyomásprofil számítását. ${ }^{16} \mathrm{~A}$ Harasima kontúr használata ugyanakkor nem teszi lehetővé a felületre merőleges (normális irányú) nyomásprofil számítását. ${ }^{17}$ Egyensúlyi rendszerek esetén azonban ez nem okoz problémát, hiszen a rendszer mechanikai stabilitása megköveteli, hogy a normális irányú nyomás értéke állandó legyen, és ez az állandó érték a két tömbfázis belsejében, azaz izotróp környezetben megegyezik a skaláris nyomásértékkel.

\section{A felületi feszültség eloszlása a felület normálisa mentén}

A felületi feszültség, molekuláris értelmezése alapján, a felületi részecskék energiahiányából adódik, ezek a részecskék ugyanis nem tudnak olyan sok, vagy olyan erős vonzó kölcsönhatást kialakítani a másik fázis közelsége miatt, mint tömbfázisbeli társaik. Mivel ez az energiahiány a fázishatártól különböző távolságra lévő részecskéket különböző mértékben érinti, felmerülhet a kérdés, hogy hogyan oszlik el ez az energiahiány, azaz a felületi feszültség a felület normálisa mentén. A felületi feszültség, mechanikai definíciója szerint, a nyomás laterális és normális irányú komponensének különbségéből adódik: 


$$
\gamma=\frac{1}{2} \int_{-\infty}^{\infty}\left(p_{\mathrm{N}}-p_{\mathrm{L}}(X)\right) \mathrm{d} X
$$

ahol $p_{\mathrm{N}}$ a nyomás normális irányú komponense (mely a felület normálisa mentén állandó), $p_{\mathrm{L}}(X)$ pedig a laterális nyomáskomponens értéke a felületre merőleges $\mathrm{X}$ tengely egy adott pontjában. (Számítógépes szimulációk során, periodikus határfeltételek alkalmazása esetén a fenti integrálást 0 és $L$ között lehet elvégezni, ahol $L$ a szimulációs doboz felületre merőleges irányú élének hossza.) Ilyen módon a felületi feszültség eloszlásának kérdése a laterális nyomásprofil számításával közvetlenül vizsgálható. Az ITIM módszer ${ }^{3,4}$ alkalmazása lehetővé teszi, hogy ezt a profilt. és így a felületi feszültség eloszlását is a Gibbs-féle elválasztó felület mellett a valódi, kapilláris hullámokkal érdesített felülethez viszonyítva is kiszámíthassuk, illetve hogy a felület alatti egymást követő molekuláris rétegeknek a felületi feszültséghez adott járulékát számszerüsíthessük.

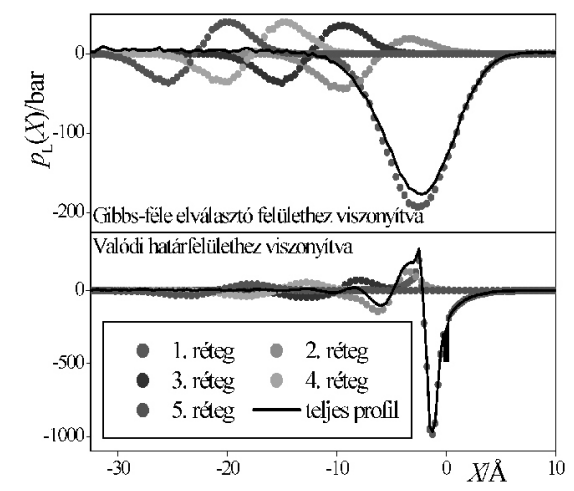

2. Ábra. Laterális nyomásprofil illetve az első öt molekuláris réteg járuléke aceton folyadék-gőz határfelületen a Gibbs-féle elválasztó felülethez (fent) illetve a valódi határfelülethez (lent) viszonyítva.

A kérdést öt molekuláris folyadék, nevezetesen széntetraklorid, aceton, acetonitril, metanol és víz folyadék-gőz határfelületén vizsgáltuk. ${ }^{24} \mathrm{E}$ folyadékok igen változatos kölcsönhatásokkal jellemezhetök: az apoláros széntetrakloridban csak van der Waals kölcsönhatás lép fel, az aceton és az acetonitril az aprotikus dipoláris anyagok közé tartozik, míg a metanol és a víz tulajdonságait a hidrogénhidas kölcsönhatások határozzák meg, de míg a metanol esetében ezek a H-kötések izolált klasztereket alkotnak, ${ }^{25}$ vízben térkitöltő hálót hoznak létre. ${ }^{26,27} \mathrm{~A}$ laterális nyomás profilját, illetve a felület alatti első öt molekuláris réteg ehhez adott járulékait mind a határfelület átlagos, külső koordinátarendszerben meghatározott pozíciójához (azaz a Gibbs-félre elválasztó felülethez), mind pedig a valódi, kapilláris hullámokkal érdesített határfelülethez viszonyítva a 2. ábra mutatja acetonban. Hasonló profilokat kaptunk a többi folyadék esetén is. ${ }^{24}$ Látható, hogy a felületi feszültség nagy része az első rétegtől származik (hiszen a teljes profil igen hasonló az első réteg járulékához). A következő rétegek járuléka az átlagos felülethez viszonyítva nem tünik el, két egymást követő, hasonló amplitúdójú, de ellenkező előjelü csúcsot láthatunk még az ötödik réteg esetében is. E két csúcs hatása nagymértékben kioltja egymást. Ha a profilokat a valódi határfelülethez viszonyítjuk, nyilvánvalóvá válik, hogy a harmadik rétegtől kezdve az egyes rétegek már lényegében nem járulnak hozzá a felületi feszültséghez. Ezt demonstrálja a 3. ábra is, mely az egyes rétegeknek a felületi feszültség értékéhez adott százalékos járulékát mutatja az öt vizsgált folyadék esetében. Látható, hogy a felületi feszültség kb. 90 \%-a az első, míg a maradék $10 \%$-a a második rétegtől származik majdnem minden esetben. Az egyetlen kivétel ebben a tekintetben a metanol, melynek felületi molekulái igen erős orientációs rendezettséget mutatnak: ${ }^{28}$ itt a felületi feszültség lényegében $100 \%$-ban az első molekuláris rétegtől származik.

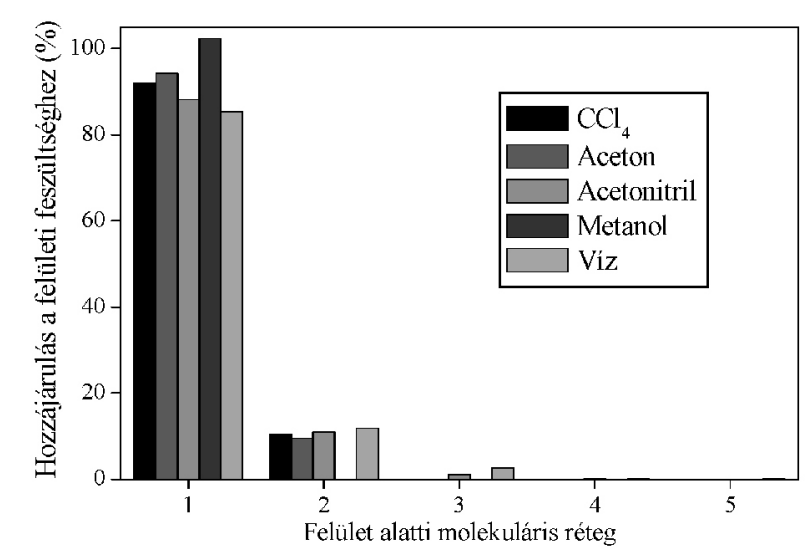

3. Ábra. Az egyes felület alatti molekuláris rétegek százalékos hozzájárulása a felületi feszültséghez a vizsgált öt molekuláris rendszer folyadék-göz határfelületén.

\section{Folyadékok stabilitási határának kapcsolata a laterális nyomásprofillal}

Folyadékok metastabil, túlhevített állapotban létezhetnek forráspontjuk felett is. Túlhevítésük, azaz stabilitásuk végső határát a $T$-p fázisdiagramon a kritikus pontból induló úgynevezett spinodális görbe jelöli ki, ezen túl a folyadékállapot már nem metastabil, hanem instabil lenne, és így nem létezhet. A spinodális görbe lefutásának legalább közelítő ismerete gyakorlati szempontból igen fontos lenne, hiszen a spinodális közelébe kerülve a rendszer heves, robbanásszerü módon kezd forrni. Ilyen explozív forrás vagy "gőzrobbanás" következhet be, ha a rendszer igen gyors nyomáscsökkenés vagy hőmérsékletnövekedés hatására (például atomreaktorok hütővízkörének vagy kompresszált gáz tartályának sérülésekor) a homogén nukleáció megkezdődése előtt, hirtelen jut a spinodálishoz közeli állapotba. ${ }^{29-31}$ Spinodálishoz közeli állapotok érhetőek el akkor is, ha a folyadék hirtelen kerül kontaktusba igen forró anyaggal (pl. magmával vagy fémolvadékkal). ${ }^{32}$ Negatív nyomású spinodálisközeli állapotok szobahőmérsékleten is elérhetőek ha folyadékot nagy amplitúdójú nyomáshullám ér, például orvosi ultrahang hatására. Az ilyenkor fellépő hirtelen kavitáció közvetlen veszélyt jelenthet a környező szövetekre. ${ }^{33}$ 
A spinodális pontos értékét kísérleti úton gyakorlatilag lehetetlen meghatározni, hiszen a spinodálishoz közeledve a folyadékban óhatatlanul jelen lévő szennyeződések a heterogén, míg a metastabilitás szintjével együtt növekvő sürüségfluktuációk a homogén nukleáció centrumaiként a rendszer hirtelen forrását okozzák a spinodális elérése előtt. Ugyanakkor a spinodális értéke legalább közelítőleg meghatározható számítógépes szimulációval a rendszer nyomásának izoterm sürüségfüggése alapján. ${ }^{34,35} \mathrm{~A}$ szimuláció során használatos potenciálmodellek zömét azonban termodinamikailag stabil, a spinodálistól távoli termodinamikai állapotokban optimálták, így jóságuk a spinodális közelében megkérdőjelezhető.

Néhány éve Imre és munkatársai felvetették, hogy a spinodális nyomás kapcsolatban állhat a gőz-folyadék határfelületen megjelenő laterális nyomásprofil minimum értékével. ${ }^{36}$ Hipotézisüket Lennard-Jones folyadék ${ }^{36}$ és $\mathrm{CO}_{2}$ esetében ${ }^{37}$ állapotegyenletekkel szemben tesztelték, míg víz esetében ezt a hipotézist használták fel különböző állapotegyenletek spinodálishoz közeli állapotokban mutatott jóságának vizsgálatára. ${ }^{31} \mathrm{Az}$ állapotegyenletek zömét azonban, a potenciálmodellekhez hasonlóan a spinodálistól távoli állapotokban paraméterezték, így jóságuk a spinodális közelében ugyancsak kétséges.

Munkánk során Imre és munkatársai hipotézisét oly módon teszteltük, hogy adott modellfolyadék laterális nyomásprofiljának minimum értékét ugyanezen modellfolyadék spinodális nyomásával vetettük össze. ${ }^{38} \mathrm{Az}$ összehasonlítást elvégeztük a Lennard-Jones folyadékra, valamint a víz SPC/E modelljére ${ }^{39}$ is. Előbbi esetben a spinodális nyomás értékeit is mi számítottuk ki, ${ }^{38}$ míg az utóbbi esetben ezek az értékek az irodalomban hozzáférhetőek voltak. ${ }^{40}$

A kétféle nyomásérték összehasonlítását a 4. ábra mutatja mindkét esetre. Amint látható víz esetén a két nyomás statisztikai hibahatáron belül egyezik, a Lennard-Jones rendszer esetén azonban csak arányosság áll fent közöttük. Mindezek alapján úgy tünik, hogy a folyadék-gőz határfelületi laterális nyomásprofil minimuma és a spinodális nyomás közötti hőmérsékletfüggetlen arányossági tényező az adott anyagi rendszer jellemzője. Eredményeink azt mutatják, hogy a két nyomás egyenlősége nem garantált, azonban a laterális nyomásprofil ismeretében a spinodális széles hőmérséklettartományban jól becsülhető, ha értékét (a kritikus pont mellett) akár egyetlen pontban is megmérjük. Ezen kívül a két nyomás víz esetén tapasztalt szerencsés egybeesése jelentősen megkönnyítheti a spinodális becslését ezen gyakorlati szempontból igen jelentős rendszer esetében.
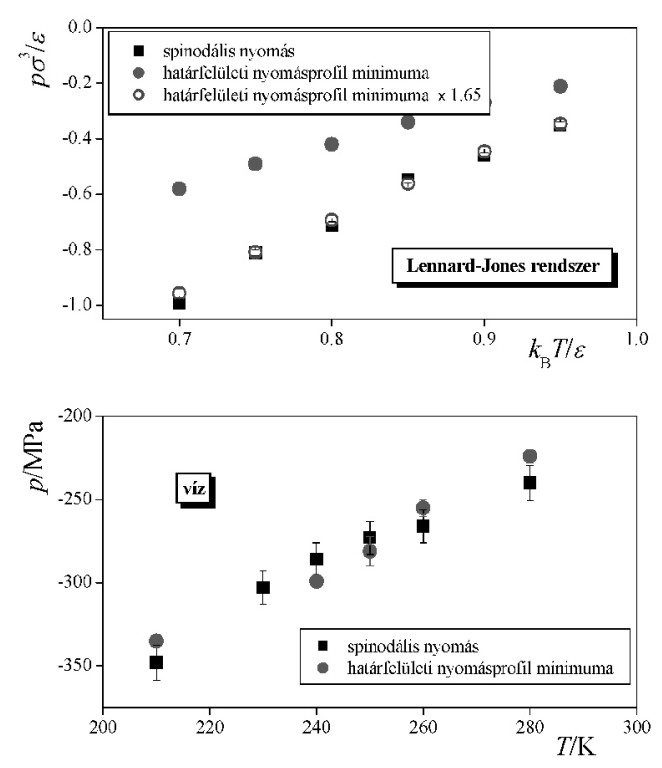

4. Ábra. A spinodális nyomás és a folyadék-gőz határfelületi laterális nyomásprofil minimumának összehasonlítása a Lennard-Jones rendszer (fent) és a víz (lent) esetén.

\section{Anesztetikumok hatásmechanizmusának vizsgálata}

Anesztetikumokat, altató hatású anyagokat több mint százötven év óta használnak rutinszerűen a sebészi gyakorlatban. Meyer ${ }^{41}$ és Overton ${ }^{42}$ munkássága óta, vagyis több mint száz éve azt is tudjuk, hogy ezek a molekulák a sejtek membránjában felhalmozódva fejtik ki hatásukat. Az anesztézia hatásmechanizmusának részleteit azonban a mai napig homály fedi. Egyes hipotézisek, az úgynevezett "fehérje elméletek" szerint ${ }^{43-45}$ e molekulák egy adott membránfehérjével lépnek specifikus kölcsönhatásba, és ez vezet az altató hatás kialakulásához. A feltételezett kölcsönhatásban részt vevő fehérjét azonban a mai napig nem azonosították. A specifikus kölcsönhatás lehetősége ellen szól az altató hatású molekulák nagy kémiai változatossága is. Egy másik lehetséges magyarázat, a "lipid elmélet" 46-50 azt feltételezi, hogy az anesztetikumok a lipid membrán valamely releváns tulajdonságát változtatják meg, ami konformációs változást indukál egyes membránfehérjékben, és ez a konformációs változás vezet végül az altató hatás kialakulásához. A membrán anesztetikumok hatására nézve megváltozó, releváns tulajdonságára nézve szintén több feltételezés hipotézis létezik. Mullins "kritikus térfogat hipotézise" szerint anesztetikumok jelenlétében csökken a membrán sürüsége, és ha a móltérfogat értéke meghalad egy kritikus értéket, fellép az anesztézia jelensége. ${ }^{46}$ Későbbi vizsgálatok a lipid láncoknak anesztetikumok jelenlétében fellépő orientációs rendeződésével, és a membrán vastagságának ilyen módon való megnövekedésével magyarázták a membrán 
móltérfogatának ezt a növekedését. ${ }^{48,49,51}$ Más magyarázatok a membrán fluiditásának változásában, 52,53 vagy az anesztetikumok önasszociációjában ${ }^{54,55}$ keresték a jelenség molekuláris magyarázatát. A kísérleti és szimulációs adatok azonban meglehetősen ellentmondásosaknak bizonyultak e tekintetben. ${ }^{55-61}$

Cantor 1997-ben elméleti megfontolások alapján felállított hipotézise szerint az anesztetikumok a membrán laterális nyomásprofilját változtatják meg, ami egyes membránfehérjék konformációs egyensúlyának eltolódásához, és végső soron az anesztetikus hatás megjelenéséhez vezet. ${ }^{50} \mathrm{E}$ hipotézis kísérleti ellenőrzése azonban gyakorlatilag lehetetlen, hiszen a laterális nyomáskomponens átlagos értékének Angström felbontású mérését igényelné a membrán normálisa mentén. A kérdés azonban számítógépes szimulációval érdemben vizsgálható.

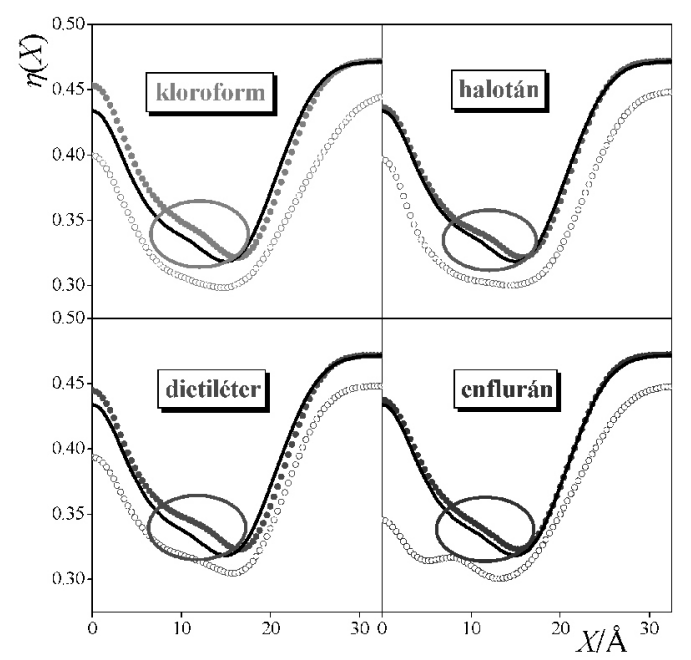

5. Ábra. A szabad térfogati hányad profilja tiszta DPPC membránban 1 bar nyomáson (fekete folytonos vonal), illetve anesztetikumot tartalmazó DPPC membránban 1 bar (tele körök) és 1000 bar (üres körök) nyomáson. A munkahipotézisünknek megfelelő változást mutató tartományt bekarikáztuk.

Az anesztézia mechanizmusával kapcsolatosan régóta ismeretes az a tény is, hogy az anesztetikus hatás nagy nyomáson megszünik. ${ }^{52,62-64}$ Ezért az anesztézia jelenségének bármilyen lehetséges molekuláris magyarázatának egyúttal számot kell tudni adnia a nyomásreverzió jelenségéről is. Korábbi munkáinkban négy anesztetikus hatású molekulát: kloroformot, halotánt, dietilétert, illetve enfluránt vizsgáltunk dipalmitoil-foszfatidilkolin (DPPC) kettős rétegben mind a gél $(\beta),{ }^{65}$ mind pedig a biológiai szempontból relevánsabb folyadékkristályos $(\alpha)$ fázisban. ${ }^{66} \mathrm{E}$ munkánk során arra a kérdésre kerestük a választ, hogy mi lehet az anesztézia jelensége mögött meghúzódó, anesztetikumok hatására szisztematikusan változó membrántulajdonság. Ennek érdekében a szimulációt anesztetikumtól mentes és anesztetikumot tartalmazó membránokon is elvégeztük mind 1 bar, mind pedig 1000 bar nyomáson. Munkahipotézisünk szerint az anesztetikus hatás mögött csak olyan membrántulajdonság változása állhat, mely (i) bármely anesztetikum hozzáadására ugyanabba az irányba, míg (ii) a nyomás növelésével ezzel ellentétes irányba változik. Vizsgálataink során egyetlen ilyen tulajdonságot találtunk, nevezetesen a membrán laterális sürüségét, ami bármelyik anesztetikum hozzáadására lecsökkent, a nyomás növelésének hatására viszont megnőtt. Ez az eredmény összhangban van a fentebb említett, hat évtizeddel ezelőtti kritikus térfogat hipotézissel ${ }^{46}$ is, habár a térfogat változását nem a membrán vastagságának növekedésével (ez a tulajdonság érzéketlennek bizonyult az anesztetikumok jelenlétére), hanem laterális tágulásával magyarázza.

E munkáinkban - a laterális nyomásprofillal kapcsolatos, a bevezetőben említett nehézségek miatt - Cantor hipotézisének vizsgálatával még nem foglalkoztunk. A 2. fejezetben részletezett módszertani fejlesztések segítségével azonban lehetővé vált számunkra a hipotézis érdemi vizsgálata is, mely nem elválasztható attól a kérdéstől sem, hogy az említett laterális tágulás a membrán mely régióját érinti elsősorban. Ezért a tíz említett szimulált rendszerben (anesztetikumtól mentes, illetve a négyféle anesztetikumot tartalmazó membrán 1 bar illetve 1000 bar nyomáson) kiszámítottuk a szabad térfogat hányadának ( $\eta$ ) illetve a nyomás laterális komponensének a profilját is. ${ }^{67}(\mathrm{~A}$ szabad térfogati hányadot az atomok által el nem foglalt, üres térrész és a teljes térfogat hányadosaként definiáltuk, és Voronoj-Delaunay analízissel ${ }^{68-70}$ számítottuk ki.)

A kapott szabad térfogati hányad illetve laterális nyomás profilokat az 5. illetve 6 . ábra mutatja. Látható, hogy a szabad térfogathányad, $e$, a membrán közepétöl 8-16 ̊ távolságra változik a munkahipotézisünkben elvárt módon, azaz ebben a tartományban minden anesztetikum megnöveli a szabad térfogathányad értékét, míg a nyomás növelése értelemszerüen csökkenti azt. Korábbi eredményeink szerint az anesztetikumok minden esetben kétféle membránbeli pozíciót preferálnak, a membrán közepe mellett attól nagyjából 10 Å távolságra, a tisztán szénhidrogénláncokból álló tartomány külső határán dúsulnak fel. ${ }^{66}$ Mindezek alapján arra következtethetünk, hogy a membrán laterális tágulását elsősorban ezek a külső pozícióban felhalmozódó anesztetikumok okozzák.

Amint a 6. ábrán látható, a laterális nyomás profilja a membrán közepétől 13-18 ^̊ távolságra változik a munkahipotézisünk szerint elvárt módon, azaz itt csökken le mindegyik anesztetikum jelenlétében. (A rendszer teljes nyomásának növelése értelemszerüen a laterális nyomásprofil egészét is ennek megfelelően eltolja 1000 bar-ral nagyobb értékekre.) A laterális nyomásprofil változása szempontjából releváns tartomány tehát, noha átfed a szabad térfogati hányad változása szempontjából releváns tartománnyal, attól némileg kifele, a fejcsoporti réteghez közelebb található, ahol a lipid láncok észter csoportjai helyezkednek el. ${ }^{66}$ Fontos megjegyezni, hogy ez a tartomány már egyáltalán nem tartalmaz anesztetikumot. ${ }^{66}$ 


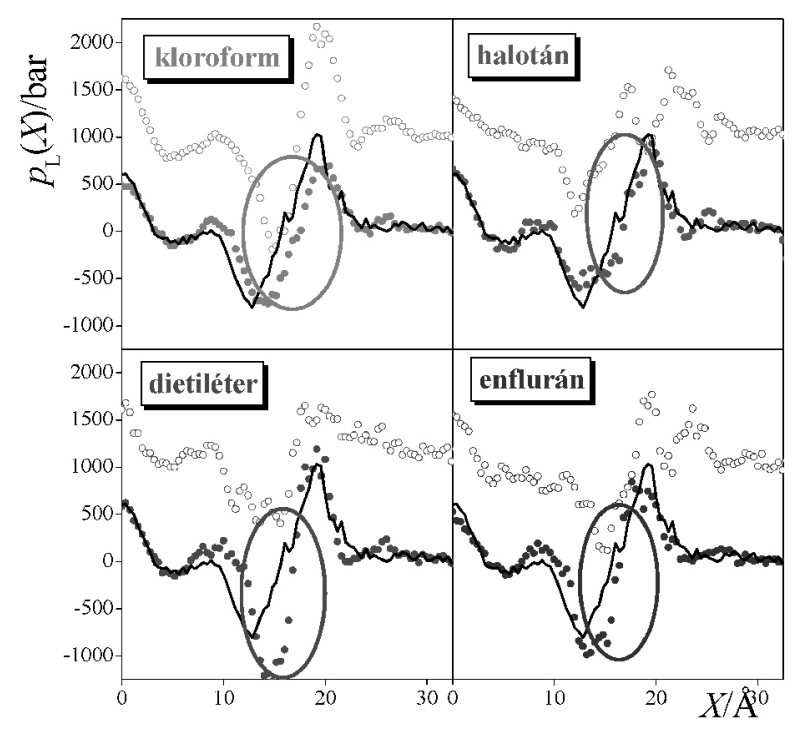

6. Ábra. A laterális nyomás profilja tiszta DPPC membránban 1 bar nyomáson (fekete folytonos vonal), illetve anesztetikumot tartalmazó DPPC membránban 1 bar (tele körök) és 1000 bar (üres körök) nyomáson. A munkahipotézisünknek megfelelő változást mutató tartományt bekarikáztuk.

Az anesztetikum hatására a szénhidrogénes fázis külső határán bekövetkező laterális dilatáció hatása értelemszerüen kiterjed a tartomány határain némileg túlra (hiszen a lipid láncok nem tudnak közvetlenül az anesztetikum molekulái mögött "összezárni"), a laterális nyomás pedig ott csökken érdemben, ahova az anesztetikum molekulái már nem jutnak el, azaz jelenlétük nem vezet a részecskeszámsürüség növekedéséhez. Mindezen eredmények nem csak összhangban vannak mind Mullins, ${ }^{46}$ mind pedig Cantor ${ }^{50}$ hipotézisével, de ok-okozati kapcsolatot is teremtenek közöttük, illetve megmutatják, hogy - amennyiben valóban a laterális nyomásprofil megváltozása áll az anesztézia jelensége mögött - a megfelelő membránfehérjék releváns konformációs változásait a membránnak at észter csoportokat tartalmazó tartományában kell keresni.

\section{Köszönetnyilvánítás}

A munka az NKFIH támogatásával készült (projektszám: 119732 és 120075). Köszönettel tartozunk Dr. Marcello Sega-nak (Universität Wien) a témában való folyamatos együttmüködésért, valamint Dr. Nikolai Medvedevnek és Dr. Vladimir Voloshinnak (Novosibirsk State University) a szabad térfogati hányad profiljának számításáért.

\section{Hivatkozások}

1. Allen, M. P.; Tildesley, D. J. Computer Simulation of Liquids; Clarendon Press: Oxford, 1987.

ISBN: 0198553757

2. Rowlinson, J. S.; Widom, B. Molecular Theory of Capillarity; Dover Publications: Mineola, 2002, p. 11. ISBN: 9780486425443

3. Pártay, L. B.; Hantal, G.; Jedlovszky, P.; Vincze, Á.; Horvai, G. J. Comput. Chem. 2008, 29, 945-956. https://doi.org/10.1002/jcc.20852

4. Jedlovszky, P. Magy. Kém. Folyóirat 2011, 117, 166-173.

5. Jorge, M.; Hantal, G.; Jedlovszky, P.; Cordeiro, M. N. D. S. J. Phys. Chem. C. 2010, 114, 18656-18663. https://doi.org/10.1021/jp107378s

6. Atkins, P. W. Physical Chemistry; Freeman: New York, 1994. ISBN: 9780198501015

7. Liquids Under Negative Pressure, Imre, A. R.; Maris, H. J.; Williams, P. R., Eds.; Kluwer: Dordrecht, 2002. ISBN 978-94-010-0498-5

8. Irving, J. H.; Kirkwood, J. G. J. Chem. Phys. 1950, 18, 817-829. https://doi.org/10.1063/1.1747782

9. Harasima, A. Adv. Chem. Phys. 1958, 1, 203-237. https://doi.org/10.1002/9780470143476.ch7

10. Sonne, J.; Hansen, F. Y.; Peters, G. H. J. Chem. Phys. 2005, 122, 124903-1-9. https://doi.org/10.1063/1.1862624

11. Ewald, P. Ann. Phys. 1921, 369, 253-287. https://doi.org/10.1002/andp.19213690304

12. de Leeuw, S. W.; Perram, J. W.; Smith, E. R. Proc. R. Soc. Lond. A 1980, 373, 27-56. https://doi.org/10.1098/rspa.1980.0135

13. Darden, T.; York, D.; Pedersen, L. J. Chem. Phys. 1993, 98, 10089-10092. https://doi.org/10.1063/1.464397

14. Essman, U.; Perera, L.; Berkowitz, M. L.; Darden, T.; Lee, H.; Pedersen, L. G. J. Chem. Phys. 1995, 103, 8577-8594. https://doi.org/10.1063/1.470117

15. Lindahl, E.; Edholm, O. J. Chem. Phys. 2000, 113, 3882-3893. https://doi.org/10.1063/1.1287423

16. Gullingsrud, J.; Schulten, K. Biophys. J. 2004, 86, 3496-3509. https://doi.org/10.1529/biophysj.103.034322

17. Patra, M. Eur. Biophys. J. 2005, 35, 79-88. https://doi.org/10.1007/s00249-005-0011-0

18. Carrillo-Trip, M.; Fellner, S. E. Biochemistry 2005, 44, 10164-10169. https://doi.org/10.1021/bi050822e

19. Ollila, S.; Hyvönen, M. T.; Vattulainen, I. J. Phys. Chem. B 2007, 111, 3139-3150. https://doi.org/10.1021/jp065424f

20. Griepernau, B.; Böckmann, R. A. Biophys. J. 2008, 95, 5766-5778. https://doi.org/10.1529/biophysj.108.142125

21. Sega, M.; Fábián, B.; Jedlovszky, P. J. Chem. Theory Comput. 2016, 12, 4509-4515. https://doi.org/10.1021/acs.jctc.6b00576

22. Sega, M.; Fábián, B.; Jedlovszky, P. J. Chem. Phys. 2015, 143, 114709-1-114709-8. https://doi.org/10.1063/1.4931180

23. Schofield, P.; Henderson, J. R. Proc. R. Soc. Lond. A 1982 , 379, 231-246. https://doi.org/10.1098/rspa.1982.0015

24. Sega, M.; Fábián, B.; Horvai, G., Jedlovszky, P. J. Phys. Chem. C 2016, 120, 27468-27477. https://doi.org/10.1021/acs.jpcc.6b09880

25. Pálinkás, G.; Hawlicka, E.; Heinzinger, K. J. Phys. Chem. 1987, 91, 4334-4341. https://doi.org/10.1021/j100300a026

26. Geiger, A.; Stillinger, F. H.; Rahman, A. J. Chem. Phys. 1979, 70, 4185-4193. https://doi.org/10.1063/1.438042

27. Stanley, H. E.; Teixeira, J. J. Chem. Phys. 1980, 73, 3404-3422. https://doi.org/10.1063/1.440538 
28. Pártay, L. B.; Jedlovszky, P.; Vincze, Á.; Horvai, G. J. Phys. Chem. B. 2008, 112, 5428-5438. https://doi.org/10.1021/jp711547e

29. Abbasi, T.; Abbasi, S. A. J. Loss Prevention in Proc. Ind. 2007, 20, 165-181. https://doi.org/10.1016/j.jlp.2005.11.002

30. Poullikkas, A. Progr. Nucl. Energy 2003, 42, 3-10. https://doi.org/10.1016/S0149-1970(03)80002-1

31. Imre, A. R.; Baranyai, A.; Deiters, U. K.; Kiss, P. T.; Kraska, T.; Quińones Cisneros, S. E. Int. J. Thermophys. 2013, 34, 2053-2064. https://doi.org/10.1007/s10765-013-1518-8

32. Lamome, J.; Meignen, R. Nucl. Engin. Design 2008, 238, 3445-3456. https://doi.org/10.1016/j.nucengdes.2008.08.006

33. Nakabaru, T.; Hashimoto, T.; Matsuo, S.; Setoguchi, T.; Rajesh, G. J. Thermal Sci. 2013, 22, 209-215. https://doi.org/10.1007/s11630-013-0614-1

34. Poole, P. H.; Sciortino, F.; Essmann, U.; Stanley, H. E. Nature 1992, 360, 324-328. https://doi.org/10.1038/360324a0

35. Poole, P. H.; Sciortino, F.; Essmann, U.; Stanley, H. E. Phys. Rev. E 1993, 48, 3799-3817. https://doi.org/10.1103/PhysRevE.48.3799

36. Imre, A. R.; Mayer, G.; Házi, G.; Rozas, R.; Kraska, T J. Chem. Phys. 2008, 128, 114708-1-11. https://doi.org/10.1063/1.2837805

37. Kraska, T.; Römer, F.; Imre, A. R. J. Phys. Chem. B 2009, 113, 4688-4697. https://doi.org/10.1021/jp808789p

38. Sega, M.; Fábián, B.; Imre, A. R.; Jedlovszky, P. J. Phys. Chem. B 2017, 121, 12214-12219. https://doi.org/10.1021/acs.jpcb.6b12437

39. Berendsen, H. J. C.; Grigera, J. R.; Straatsma, T. J. Phys. Chem. 1987, 91, 6269-6271. https://doi.org/10.1021/j100308a038

40. Netz, P. A.; Starr, F. W.; Stanley, H. E.; Barbosa, M. C. J. Chem. Phys. 2001, 115, 344-348. https://doi.org/10.1063/1.1376424

41. Meyer, H. Naunyn-Schmiedebergs Archiv für Experimentelle Pathologie und Pharmakologie 1899, 42, 109-118. https://doi.org/10.1007/BF01834479

42. Overton, E. Studien über die Narkose zugleich ein Beitrag zur allgemeinen Pharmakologie; Gustav Fischer Verlag: Jena, 1901.

43. Kao, C. Y. Pharmacol. Rev. 1966, 18, 997-1049. PMID: 5328391

44. Lee, A. G. Nature 1976, 262, 545-548. https://doi.org/10.1038/262545a0

45. Franks, N. P.; Lieb, W. R. Nature 1994, 367, 607-614. https://doi.org/10.1038/367607a0

46. Mullins, L. J. Some Physical Mechanisms in Narcosis. Chem. Rev. 1954, 54, 289-323. https://doi.org/10.1021/cr60168a003

47. Miller, K. W.; Pang, K. Nature 1976, 263, 253-255. https://doi.org/10.1038/263253a0

48. Haydon, D. A.; Hendry, B. M.; Levinson, S. R.; Requena, J. Nature 1977, 268, 356-358. https://doi.org/10.1038/268356a0

49. Ashcroft, R. G.; Coster, H. G. L.; Smith, J. R. Nature 1977, 269, 819-820. https://doi.org/10.1038/269819a0
50. Cantor R. S. Biochemistry 1997, 36, 2339-2344. https://doi.org/10.1021/bi9627323

51. Ashcroft, R. G.; Coster, H. G. L.; Smith, J. R. Biochim. Biophys. Acta 1977, 469, 13-22. https://doi.org/10.1016/0005-2736(77)90321-2

52. Trudell, J. R.; Payan, D. G.; Chin, J. H., Cohen, E. N. Proc. Natl. Acad. Sci. USA 1975, 72, 210-213. https://doi.org/10.1073/pnas.72.1.210

53. Forrest, B. J.; Rodham, D. K. BBA - Biomembranes 1985, 814, 281-288. https://doi.org/10.1016/0005-2736(85)90446-8

54. Chau, P. L.; Hoang, P. N. M.; Picaud, S.; Jedlovszky, P. Chem. Phys. Lett. 2007, 438, 294-297. https://doi.org/10.1016/j.cplett.2007.02.071

55. Chau, P. L.; Hoang, P. N. M.; Picaud, S.; Jedlovszky, P. J. Mol. Liquids 2009, 147, 128-134. https://doi.org/10.1016/j.molliq.2008.09.005

56. Turner, G. L.; Oldfield, E. Nature 1979, 277, 669-670. https://doi.org/10.1038/277669a0

57. Franks, N. P.; Lieb, W. R. J. Mol. Biol. 1979, 133, 469-500. https://doi.org/10.1016/0022-2836(79)90403-0

58. Trudell, J. R.; Hubbell, W. L.; Cohen, E. N. BBA Biomembranes 1973, 291, 321-327. https://doi.org/10.1016/0005-2736(73)90485-9

59. Koubi, L.; Tarek, M.; Klein, M. L.; Scharf, D. Biophys. J. 2000, 78, 800-811.

https://doi.org/10.1016/S0006-3495(00)76637-9

60. Porasso, R. D.; Drew Bennett, W. F.; Oliveira-Costa, S. D.; López-Cascales, J. J. J. Phys. Chem. B 2009, 113, 9988-9994. https://doi.org/10.1021/jp902931s

61. Chen, J.; Chen, L.; Wang, Y.; Wang, X.; Zeng, S. Sci. Rep. 2015, 5, 17235-1-6. https://doi.org/10.1038/srep17235

62. Johnson, F. H.; Flagler, E. A. Science 1950, 112, 91-92. https://doi.org/10.1126/science.112.2899.91-a

63. Lever, M. J.; Miller, K. W.; Paton, W. D. M.; Smith, E. B. Nature 1971, 231, 368-371. https://doi.org/10.1038/231368a0

64. Halsey, M. J.; Wardley-Smith, B. Nature 1975, 257 , 811-813. https://doi.org/10.1038/257811a0

65. Darvas, M.; Hoang, P. N. M.; Picaud, S.; Sega, M.; Jedlovszky, P. Phys. Chem. Chem. Phys. 2012, 14, 12956-12969. https://doi.org/10.1039/c2cp41581j

66. Fábián, B.; Darvas, M.; Picaud, S.; Sega, M.; Jedlovszky, P. Phys. Chem. Chem. Phys. 2015, 17, 14750-14760. https://doi.org/10.1039/C5CP00851D

67. Fábián, B.; Sega, M.; Voloshin, V. P.; Medvedev, N. N.; Jedlovszky, P. J. Phys. Chem. B 2017, 121, 2814-2824. https://doi.org/10.1021/acs.jpcb.7b00990

68. Voronoi, G. F. J. Reine Angew. Math. 1908, 134, 198-287.

69. Delaunay, B. N. Izv. Akad. Nauk. SSSR, Otd. Math. Est. Nauk. 1934, 7, 793-800.

70. Okabe, A.; Boots, B.; Sugihara, K.; Chiu, S. N. Spatial Tessellations: Concepts and Applications of Voronoi Diagrams, John Wiley: Chichester, 2000. https://doi.org/10.1002/9780470317013 ISBN: 978-0-471-98635-5 


\section{Computer simulation investigation of problems related to the calculation of the lateral pressure profile}

The calculation of the lateral pressure profile in computer simulations of anisotropic systems is an important problem in various respects; however, it is not a straightforward task at all. The difficulty of its calculation mainly stems from the fact that pressure (more specifically, its configurational part) is an inherently non-local quantity, which has to be localized in the profile calculation. Further, if an Ewald summation-based method is used to account for the long range part of the intermolecular interactions, the reciprocal space term of this correction is not pairwise additive. We proposed an accurate and computationally very efficient way, employing the Harasima path, of calculating the profile of the lateral pressure, which can also take into account the reciprocal space term when using the sPME method. Further, we presented here three applications of the lateral pressure profile calculation.

Using an intrinsic surface analyzing method, such as the Identification of the Truly Interfacial Molecules (ITIM), the subsequent subsurface layers beneath the liquid-vapor interface can be unambiguously identified. Since the surface tension is closely related to the lateral pressure profile, having the contribution of the individual molecular layers to this profile determined, their surface tension contribution can also be calculated. We performed such a calculation for the liquid-vapor interface of five molecular systems characterized by markedly different intermolecular interactions, namely carbon tetrachloride, acetone, acetonitrile, methanol and water. Our results showed that at least $90 \%$ of the surface tension comes from the first molecular layer in every case, and in methanol this contribution practically reaches $100 \%$.
We checked the conjecture of Imre et al. concerning the relation of the spinodal pressure with the minimum value of the lateral pressure profile at the liquid-vapor interface by comparing these values in a broad temperature range, as obtained both for the Lennard-Jones system and water. We found proportionality between the two pressure values, but their ratio turned out to be system dependent. For water, this value is found to be unity, indicating that the two pressures are equal to each other. This finding may have practical consequences in determining the spinodal line of water, a liquid for which this information is of great importance.

In studying the effect of anesthetic molecules on the properties of lipid membranes we earlier showed that, unlike a number of various other membrane properties, the lateral density of the membrane changes in such a way (i.e., decreases upon adding any kind of anesthetics, and increases upon increasing the pressure) that this change can be behind the molecular mechanism of anesthesia. We showed that this lateral expansion occurs in the outer edge of the hydrocarbon region, leading also to the decrease of the lateral pressure in the nearby region of the ester groups. This way, we found a relation between our earlier results and both the more than sixty years old critical volume hypothesis of Mullins and the twenty years old lateral pressure hypothesis of Cantor. Our results thus make these hypotheses more plausible, and show that if indeed the lateral pressure induced conformational changes of certain membrane-bound proteins are responsible for the molecular mechanism of anesthesia; these conformational changes are expected to occur in the region of the lipid ester groups. 